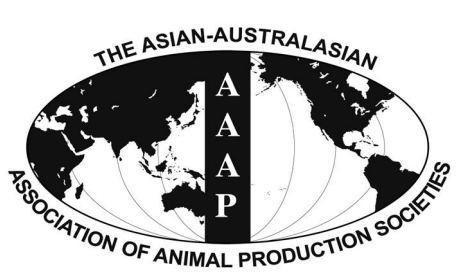

Open Access

Asian Australas. J. Anim. Sci.

Vol. 28, No. 10 : 1449-1453 October 2015

http://dx.doi.org/10.5713/ajas.15.0016

www.ajas.info

pISSN 1011-2367 elSSN 1976-5517

\title{
Effects of Replacement of Concentrate Mixture by Broccoli Byproducts on Lactating Performance in Dairy Cows
}

\author{
X. W. Yi, F. Yang, J. X. Liu, and J. K. Wang* \\ Institute of Dairy Science, College of Animal Sciences, Zhejiang University, Hangzhou 310058, China
}

\begin{abstract}
The objective of the present study was to determine the effects of feeding pelletized broccoli byproducts (PBB) on milk yield and milk composition in dairy cows. In Trial 1, an in vitro gas test determined the optimal replacement level of PBB in a concentrate mixture in a mixed substrate with Chinese wild ryegrass hay $(50: 50$, w/w) at levels of $0,10 \%, 20 \%, 30 \%$, or $40 \%$ (dry matter basis). When the concentrate was replaced by PBB at a level of $20 \%$, no adverse effects were found on the gas volume or its rate constant during ruminal fermentation. In trial 2, 24 lactating cows (days in milk $=170.4 \pm 35$; milk yield $=30 \pm 3 \mathrm{~kg} / \mathrm{d}$; body weight $=580$ $\pm 13 \mathrm{~kg}$ ) were divided into 12 blocks based on day in milk and milk yield and randomly allocated to two dietary treatments: a basic diet with or without PBB replacing $20 \%$ of the concentrate mixture. The feeding trial lasted for 56 days; the first week allowed for adaptation to the diet. The milk composition was analyzed once a week. No significant difference in milk yield was observed between the two groups (23.5 vs $24.2 \mathrm{~kg}$ ). A significant increase was found in milk fat content in the PBB group ( $\mathrm{p}<0.05)$. Inclusion of PBB did not affect milk protein, lactose, total solids or solids-not-fat $(\mathrm{p}>0.05)$. These results indicated that PBB could be included in dairy cattle diets at a suitable level to replace concentrate mixture without any adverse effects on dairy performance. (Key Words: Broccoli Byproducts, Rumen Fermentation, Milk Yield, Milk Composition)
\end{abstract}

\section{INTRODUCTION}

Broccoli (Brassica oleracea) is a popular vegetable because of its attractive green color and high nutritional value (Martínez-Villaluenga et al., 2008). Many studies have focused on extracting bioactive metabolites from the edible parts of broccoli (Assad et al., 2014; Mahn et al., 2014), extending the shelf life and maintaining the visual quality and content of bioactive compounds in broccoli florets (Peng et al., 2015). However, the byproducts (in China about 200,000 tons of leaves and roots per year [Su et al., 2005]) are left in the fields, leading not only to a waste of resources but also to a detrimental effect on the environment.

There is widespread interest in developing nonconventional feedstuffs to replace concentrates (Wang et al., 2007; Lodge-Ivey et al., 2014). Wang et al. (2007) reported

\footnotetext{
* Corresponding Author: J. K. Wang. Tel: +86-571-88982398, Fax: +86-571-88982930, E-mail: jiakunwang@zju.edu.cn Submitted Jan. 6, 2015; Revised Mar. 23, 2015; Accepted Apr. 15, 2015
}

that Porphyra haitanensis (a species of algae) could be used as a protein source in ruminant diets. It has also been found that diets including $20 \%$ Ulva lactuca were not refused by ruminants (Arieli et al., 1993). Yi et al. (2008) found that broccoli byproducts were possibly a suitable feedstuff because of their high protein content and low cost. They found little effect on in vitro gas production (GP) and ruminal fermentation in ruminant diets after replacing SBM with pelletized broccoli residues. Because broccoli is rich in protein, vitamins and phenolics (Martínez-Villaluenga et al., 2008), utilization of pelletized broccoli byproducts (PBB) as a source of concentrates for livestock may be beneficial to both animal production and the environment. However, little information is available on the effects of replacing concentrate mixture with PBB.

Therefore, the objective of the present study was to evaluate the effects of replacing concentrate mixture with different levels of PBB on in vitro fermentation (Trial 1) and the lactation performance of dairy cows (Trial 2). 
later analysis of fat, protein and lactose by infrared analysis (Laporte and Paquin, 1999) using a four-channel spectrophotometer (Milk-o-Scan, Foss Electric A/S, Hillerød, Denmark).

\section{Chemical analyses}

The PBB was ground to pass through a 1-mm sieve for subsequent analysis. The DM contents were determined according to method No. 942.05 (AOAC, 1997). The samples were analyzed for crude protein (CP) (method 988.05), acid detergent fiber (ADF) (method 973.18, AOAC, 1997) and neutral detergent fiber (NDF) by the method of Van Soest et al. (1991). Amylase, but not sulfite was used in the determination of NDF. Both NDF and ADF were expressed exclusive of residual ash. Samples of SBM, CRH and corn meal were milled to pass through a 1-mm screen and then stored for later determination of chemical composition as described above.

\section{In situ degradation}

The in situ disappearance of DM and CP for SBM, CRH and corn meal was determined using three ruminally cannulated sheep $(\mathrm{BW}=35 \pm 5 \mathrm{~kg})$ housed in individual stalls. The basal diet (\%of DM) consisted of 70\% CRH and $30 \%$ concentrate mixture fed twice daily at a level to meet the requirement for 1.3 times maintenance. The samples were ground to pass through a 4-mm screen in a mill (Thomas-Wiley Laboratory Mill; Arthur H. Thomas, Philadelphia, PA, USA). The nylon bags $(8 \times 12 \mathrm{~cm} ; 40-$ mesh pore size) containing $5 \mathrm{~g}$ of each sample were tied to the end of a 14-cm nylon line and then placed in the ventral sac of the rumen through the ruminal cannula to incubate for $24 \mathrm{~h}$. After removal from the rumen, the bags were rinsed thoroughly in cool running tap water until the wash water ran clear. The samples were dried in an oven at $65^{\circ} \mathrm{C}$ for $48 \mathrm{~h}$ and weighed to determine the residue weight. The residues and original diet samples were ground to pass through a 1-mm screen in a Cyclotec mill (Tecator 1093; Tecator AB, Höganäs, Sweden) before analysis of DM and CP. The in situ degradation of DM and CP was calculated based on the differences in weight between the residues and original diet samples.

\section{Statistical analysis}

The effects of PBB on GP, fermentation parameters, milk yield and milk composition were analyzed using the one-way analysis of variance, with themeans compared using Duncan's new multiple range test at a level of significance of 0.05 (SAS, 2000)..

\section{RESULTS AND DISCUSSION}

\section{Chemical composition of the pelletized broccoli}

\section{byproducts}

Table 2 presents the results for chemical composition and in sacco degradability of $\mathrm{PBB}, \mathrm{SBM}$, corn meal and CRH. The CP content in PBB was $21.6 \%$ (DM basis), higher than that of corn meal $(9.2 \%)$, but lower than SBM (47.9\%). The contents of NDF (47.1\%) and ADF (38.3\%) of PBB were higher than those of corn $(14.3 \%$ and $6.7 \%)$ and SBM (14.0\% and 10.7\%), but lower than CRH (70.2\% and $62.6 \%$ ). The mean disappearance of $\mathrm{DM}$ in the rumen was $88.2 \%$ in $\mathrm{PBB}$, higher than that of corn meal $(72.6 \%)$, but lower than that of SBM (94.6\%). This shows that PBB is a highly digestible feed resource with a CP level comparable with that of alfalfa hay (MoA, 2004). The calculated net energy for lactation $\left(\mathrm{NE}_{\mathrm{L}}\right)$ content was lower than that of corn, much higher than that of $\mathrm{CRH}$, but comparable with that of SBM. The basic diet with PBB replacing $20 \%$ of the concentrate mixture may meet the requirement of $\mathrm{NE}_{\mathrm{L}}$ for milk production at about 20 to 30 $\mathrm{kg} / \mathrm{d}$ (MoA, 2004).

\section{Gas production and fermentation characteristics}

As shown in Table 3, with an increasing proportion of PBB in the concentrate, the GP and potential GP values of the mixed substrates decreased, but decrease of GP and potential GP were only significant from the replacement level of $40 \%$ and $30 \% \quad(p<0.05)$ respectively. Gas production gives a measure of the degradation of substrate, particularly the carbohydrate fraction (Menke et al., 1979). These results have revealed that replacing concentrate with PBB for ruminants might not affect digestion if the replacement level was at less than $30 \%$.

Maintaining a stable rumen environment is critical. In this experiment, there was no difference $(\mathrm{p}>0.05)$ in $\mathrm{pH}$ among the five replacement levels (Table 3). The concentration of ammonia- $\mathrm{N}$ was significantly lower at the

Table 2. Chemical composition and in situ degradability of pelletized broccoli byproducts (PBB), SBM, corn meal and Chinese wild ryegrass hay (CRH)

\begin{tabular}{lcccc}
\hline & PBB & SBM & Corn & CRH \\
\hline Chemical composition & & & & \\
DM (\%) & 85.0 & 88.0 & 85.1 & 88.8 \\
CP (\% of DM) & 21.6 & 47.9 & 9.2 & 7.5 \\
NDF (\% of DM) & 47.1 & 13.0 & 14.3 & 70.2 \\
ADF (\% of DM) & 38.3 & 10.7 & 6.7 & 62.6 \\
NE $_{\mathrm{L}}^{1}$ (Mcal/kg of DM) & 1.51 & 1.63 & 1.93 & 0.79 \\
Disappearance (\%) & & & & \\
$\quad$ DM & 88.2 & 94.6 & 72.6 & 33.6 \\
CP & 50.2 & 51.4 & 10.7 & 5.6 \\
\hline
\end{tabular}

SBM, soybean meal; PBB, pelletized broccoli byproducts; DM, dry matter; $\mathrm{CP}$, crude protein; NDF, Neutral detergent fiber; ADF, Acid detergent fiber; $\mathrm{NE}_{\mathrm{L}}$, net energy for lactation.

${ }^{1}$ Calculated according to Ministry of Agriculture of P. R. China individual feedstuffs recommendations (MoA, 2004).

${ }^{2}$ In situ disappearance from nylon bag at $24 \mathrm{~h}$ (Ørskov et al., 1980). 
Table 3. Gas production (GP) and fermentation parameters of mixed substrates with pelletized broccoli byproducts (PBB) at different levels of substitution after incubation at $24 \mathrm{~h}$

\begin{tabular}{|c|c|c|c|c|c|c|c|}
\hline & \multirow{2}{*}{ PBB } & \multicolumn{6}{|c|}{ Levels of PBB (\%, DM basis) } \\
\hline & & 0 & 10 & 20 & 30 & 40 & SEM \\
\hline \multicolumn{8}{|l|}{ GP parameters $^{1}$} \\
\hline $\mathrm{GP}(\mathrm{mL})$ & 37.4 & $43.0^{\mathrm{a}}$ & $42.0^{\mathrm{a}}$ & $40.5^{\mathrm{ab}}$ & $39.9^{\mathrm{ab}}$ & $37.5^{\mathrm{bc}}$ & 1.88 \\
\hline$a+b(\mathrm{~mL})$ & 35.9 & $47.5^{\mathrm{a}}$ & $46.3^{\mathrm{ab}}$ & $46.8^{\mathrm{ab}}$ & $43.8^{\mathrm{c}}$ & $44.9^{\mathrm{bc}}$ & 0.70 \\
\hline$c(\% / \mathrm{h})$ & 7.7 & $7.6^{\mathrm{a}}$ & $6.9^{\mathrm{ab}}$ & $7.3^{\mathrm{ab}}$ & $6.6^{\mathrm{b}}$ & $5.3^{\mathrm{c}}$ & 0.14 \\
\hline \multicolumn{8}{|l|}{ Fermentation parameters } \\
\hline $\mathrm{pH}$ & 6.81 & 6.88 & 6.87 & 6.86 & 6.87 & 6.86 & 0.024 \\
\hline Ammonia-N (mg/dL) & 29.5 & $25.6^{\mathrm{ab}}$ & $25.0^{\mathrm{b}}$ & $27.2^{\mathrm{a}}$ & $26.8^{\mathrm{a}}$ & $26.9^{\mathrm{a}}$ & 0.42 \\
\hline Total VFA $(\mathrm{mmol} / \mathrm{L})$ & 48.2 & $34.9^{\mathrm{c}}$ & $35.5^{\mathrm{bc}}$ & $35.3^{\mathrm{bc}}$ & $37.3^{\mathrm{a}}$ & $36.4^{\mathrm{ab}}$ & 0.28 \\
\hline \multicolumn{8}{|c|}{ Proportion (mmol/100 mmol) } \\
\hline Acetate $(\%)$ & 75.0 & $75.4^{\mathrm{b}}$ & $76.3^{\mathrm{ab}}$ & $76.6^{\mathrm{ab}}$ & $77.2^{\mathrm{ab}}$ & $78.0^{\mathrm{a}}$ & 0.81 \\
\hline Propionate $(\%)$ & 17.0 & $16.1^{\mathrm{a}}$ & $15.7^{\mathrm{ab}}$ & $15.5^{\mathrm{ab}}$ & $15.3^{\mathrm{ab}}$ & $14.9^{\mathrm{b}}$ & 0.18 \\
\hline Butyrate (\%) & 8.0 & 8.5 & 8.1 & 7.8 & 7.5 & 7.1 & 0.35 \\
\hline Ac:Pro ratio & 4.4 & $4.7^{\mathrm{b}}$ & $4.9^{\mathrm{ab}}$ & $4.9^{\mathrm{ab}}$ & $5.0^{\mathrm{ab}}$ & $5.1^{\mathrm{a}}$ & 0.03 \\
\hline
\end{tabular}

SEM, standard error of the mean; VFA, volatile fatty acid; Ac:pro, acetate:propionate.

${ }^{1} a, b$ and $c$ : constants in the model GP $=a+b\left(1-\mathrm{e}^{-c t}\right)$ (Ørskov et al., 1980).

${ }^{a, b, c}$ Means within the same row with different superscripts differ significantly $(\mathrm{p}<0.05)$.

$10 \%$ replacement level of $\mathrm{PBB}$ in the mixed substrate than at other levels. However, it was still within a suitable range of ammonia-N concentrations $(>5 \mathrm{mg} / \mathrm{dL})$ to ensure maximum microbial growth in vitro (Satter and Slyter, 1974) and that required for optimal fiber digestion (Kennedy et al., 1992). The concentration of total VFA was enhanced significantly by replacing $\mathrm{PBB}$ at levels of $30 \%$ to $40 \%$, indicating that the availability of energy from $\mathrm{PBB}$ was adequate (Srinivas and Gupta, 1997). Replacing PBB at a level of $40 \%$ enhanced the molar proportion of acetate $(p<0.05)$ and depressed the proportion of propionate $(p<0.05)$. This change may have a negative effect on energy use because propionate increases energy use efficiency by decreasing energy losses on inter-species hydrogen transfer and methane production in the rumen (Van Houtert, 1993). Based on the above results (both chemical composition and in vitro degradation), a $20 \%$ replacement level of concentrate by PBB was chosen for the dairy cows' diet.

\section{Milk yield and milk composition}

As shown in Table 4, milk yield was not affected when PBB was included in the dairy cows' diet at a level of $20 \%$ (24.2 vs $23.5 \mathrm{~kg})$. However, including PBB significantly increased the percentage of milk fat $(\mathrm{p}<0.05)$, but had no significant effects on the percentages of milk protein, lactose, total solids and solids-not-fat ( $\mathrm{p}>0.05)$.

The higher fat content may be attributed to the higher content of NDF and ADF (Table 2) and the slightly higher proportion of acetate (Table 3) in PBB compared with the other concentrate ingredients such as corn and SBM. This is because the contents of acetate and butyrate have a positive correlation with milk fat concentration while propionate has a negative correlation (Sutton et al., 1993; 1998). Eastridge et al. (2009) found that an increase in ADF results in a higher milk fat content and thus a higher fat-corrected milk yield for cows fed straw. In the present study, the intake of fibrous materials should be higher in the diet containing PBB than in the control diet containing no PBB.

\section{CONCLUSION}

Replacing concentrate with 20\% PBB had no adverse effects on rumen fermentation, but increased milk production numerically, and increased milk fat content significantly in lactating dairy cows. The increased use of PBB in the future would be beneficial for developing a more efficient use of resources, and make ruminant milk

Table 4. Effects of feeding pelletized broccoli byproducts (PBB) on milk composition and milk production

\begin{tabular}{|c|c|c|c|}
\hline & \multicolumn{2}{|c|}{$\begin{array}{l}\text { Levels of PBB } \\
(\%, D M \text { basis })\end{array}$} & \multirow[t]{2}{*}{ SEM } \\
\hline & 0 & 20 & \\
\hline \multicolumn{4}{|l|}{ Milk production $(\mathrm{kg} / \mathrm{d})$} \\
\hline Milk yield & 23.5 & 24.2 & 1.29 \\
\hline $4 \%$ fat-corrected milk & 0.79 & 0.87 & 0.042 \\
\hline Milk protein & 0.82 & 0.77 & 0.013 \\
\hline Lactose & 1.28 & 1.22 & 0.019 \\
\hline \multicolumn{4}{|l|}{ Milk composition ( $\%)$} \\
\hline Fat & $3.16^{\mathrm{b}}$ & $3.56^{\mathrm{a}}$ & 0.127 \\
\hline Protein & 3.26 & 3.17 & 0.053 \\
\hline Lactose & 5.13 & 4.96 & 0.077 \\
\hline Total solids & 12.27 & 12.17 & 0.240 \\
\hline Solids not fat & 9.08 & 8.80 & 0.126 \\
\hline
\end{tabular}

DM, dry matter; SEM, standard error of the mean.

${ }^{\mathrm{a}, \mathrm{b}}$ Means within same row with different superscripts differ significantly $(\mathrm{p}<0.05)$. 
production more environmentally friendly.

\section{ACKNOWLEDGMENTS}

The authors gratefully acknowledge Mr. Hong-wei Ye, and the staff of the Hangzhou Zhengxing Animal Industry Company for their assistance in animal feeding and care.

\section{REFERENCES}

Arieli, A., D. Sklan, and G. Kissil. 1993. A note on the nutritive value of Ulva lactuca for ruminants. Anim. Sci. 57:329-331.

AOAC. 1997. Official Methods of Analysis, 16th ed. Association of Official Analytical Chemists, Arlington, VA, USA.

Assad, T., R. A. Khan, and Z. Feroz. 2014. Evaluation of hypoglycemic and hypolipidemic activity of methanol extract of Brassica oleracea. Chin. J. Nat. Med. 12:648-653.

Eastridge, M. L., P. B. Bucci, and C. V. D. M. Ribeiro. 2009. Feeding equivalent concentrations of forage neutral detergent fiber from alfalfa hay, grass hay, wheat straw, and whole cottonseed in corn silage based diets to lactating cows. Anim. Feed Sci. Technol. 150:86-94.

Hu, W. L., J. X. Liu, J. A. Ye, Y. M. Wu, and Y. Q. Guo. 2005. Effect of tea saponin on rumen fermentation in vitro. Anim. Feed Sci. Technol. 120: 333-339.

Kennedy, P. M., A. N. Boniface, Z. J. Liang, D. Muller, and R. M. Murray. 1992. Intake and digestion in swamp buffaloes and cattle. 2. The comparative response to urea supplements in animals fed tropical grasses. J. Agric. Sci. 119:243-254.

Laporte, M. F. and P. Paquin. 1999. Near-infrared analysis of fat, protein, and casein in cow's milk. J. Agric. Food Chem. 47: 2600-2605.

Lodge-Ivey, S. L., L. N. Tracey, and A. Salazar. 2014. Ruminant Nutrition Symposium: The utility of lipid extracted algae as a protein source in forage or starch-based ruminant diets. J. Anim. Sci. 92:1331-1342.

Mahn, A., A. Angulo, and F. Cabañas. 2014. Purification and Characterization of Broccoli (Brassica oleracea var. italica) Myrosinase ( $\beta$-Thioglucosidase Glucohydrolase). J. Agric. Food Chem. 62: 11666-11671.

Martínez-Villaluenga, C., J. Frías, P. Gulewicz, K. Gulewicz, and C. Vidal-Valverde. 2008. Food safety evaluation of broccoli and radish sprouts. Food Chem. Toxicol. 46:1635-1644.

Menke, K. H. and H. Steingass. 1988. Estimation of the energetic feed value obtained from chemical analysis and gas production using rumen fluid. Anim. Res. Dev. 28:7-55.
Menke, K. H., L. Raab, A. Salewski, H. Steingass, D. Fritz, and W. Schneider. 1979. The estimation of the digestibility and metabolizable energy content of ruminant feedingstuffs from the gas production when they are incubated with rumen liquor in vitro. J. Agric. Sci. (Camb.) 93:217-222.

MoA (Ministry of Agriculture, P.R. China). 2004. Feeding Standard of Fattening Sheep. (NY/T816-2004). Ministry of Agriculture of P. R. China, Beijing, China.

Ørskov, E. R., F. D. D. Hovell, and F. Mould. 1980. The use of the nylon bag technique for the evaluation of feedstuffs. Trop. Anim. Prod. 5:195-213.

Peng, J., D. Yao, F. Xu, H. Q. Wang, and Y. H. Zheng. 2015. Effect of light on quality and bioactive compounds in postharvest broccoli florets. Food Chem. 172:705-709.

SAS Institute Inc. 2000. SAS User's Guide: Statistics. Version 8.01. SAS Inst. Inc., Cary, NC, USA.

Satter, L. D. and L. L. Slyter. 1974. Effect of ammonia concentration on rumen microbial protein production in vitro. Br. J. Nutr. 32:199-208.

Srinivas, B. and B. N. Gupta. 1997. Rumen fermentation, bacterial and total volatile fatty acid (TVFA) production rates in cattle fed on urea-molasses-mineral-block licks supplement. Anim. Feed Sci. Technol. 65:275-286.

Su, Y. J., X. Y. Wang, and W. L. Li. 2005. Broccoli in Linghai. China Agro-technology Extension, Linhai, China. 5:1-3.

Sutton, J. D., W. H. Broster, E. Schuller, D. J. Napper, V. J. Broster, and J. A. Bines. 1988. Influence of plane of nutrition and diet composition on rumen fermentation and energy utilization by dairy cows. J. Agric. Sci. (Camb.) 110:261-270.

Sutton, J. D., S. V. Morant, J. A. Bines, D. J. Napper, and D. I. Givens. 1993. Effect of altering the starch: fibre ration in the concentrates on hay intake and milk production by Friesian cows. J. agric. Sci., Camb. 120:379-390.

Van, Houtert, M. F. J. 1993. The production and metabolism of volatile fatty acids by ruminants fed roughages: A review. Anim. Feed Sci. Technol. 43:189-225.

Van Soest, P. J., J. B. Robertson, and B. A. Lewis. 1991. Methods for dietary fiber, neutral detergent fiber, and nonstarch polysaccharides in relation to animal nutrition. J. Dairy Sci. 74: 3583-3598

Wang, J. K., H. L. Mao, Y. W. Zhou, J. X. Liu, and X. J. Yan. 2007. Feasibility of Porphyra haitanensis as protein source for ruminants. J. Anim. Feed Sci. 16:278-283.

Yi, X. W., F. Yang, Y. Chen, J. K. Wang, and J. X. Liu. 2008. Feasibility of Broccoli residues as protein source for ruminants. Proceedings of the 13th AAAP Animal Science Congress, September 22-26, 2008, Hanoi, Vietnam. 